Journal of The Indonesian Nutrition Association p-ISSN: 0436-0265 e-ISSN: 2528-5874

http://ejournal.persagi.org/index.php/Gizi_Indon

\title{
HUBUNGAN BODY IMAGE DAN SIKAP TERHADAP MAKANAN DENGAN POLA MAKAN MAHASISWI JURUSAN GIZI POLITEKNIK
}

\author{
The Correlation of Body Image, Attitude toward Food with Food Pattern \\ Female Students of Nutrition Health Polytechnic
}

Rijanti Abdurrachim, Eka Meladista, Rusmini Yanti

Politeknik Kesehatan Kemenkes Banjarmasin Jurusan Gizi

E-mail: rijanti63@yahoo.com

\section{ABSTRACT}

The body image of a nutritionist will have an impact on the quality of health services for nutritionists by providing evidence and examples to patients. This study aims to find out the relationship between body image, and attitude towards food with dietary pattern of the students of Banjarmasin Health Polytechnic Department. This study design was cross-sectional. The study was conducted in April - May 2017 with a sample of 132 female students at level 1, 2 and 3 . The sampling method was stratified random sampling. Data analysis used Spearman rank correlation test with $\alpha=0.05$. The results showed that 44.7 percent of students had a positive body image and a negative body image of 55.3 percent of female students. 46.2 percent of students had positive attitudes towards food and 53.8 percent had negative ones. As many as 59 percent had a good diet and 41 percent had a poor one. There was no relationship between body image and attitude towards food $(p=0.725)$, and there was a relationship between attitudes toward food and diet $(p=0.016)$. The conclusion of this study was that most Nutrition Department students had a good diet, negative attitudes toward food, and negative body image. The Nutrition Department was expected to be able to provide knowledge and socialization about body image to students by increasing the intake of vegetable, vegetable and fruit dishes per day as recommended, and applying a good diet.

Keyword: body image, attitude toward food, food pattern

\section{ABSTRAK}

Body image seorang ahli gizi akan berdampak pada kualitas pelayanan kesehatan ahli gizi dengan memberikan bukti dan contoh kepada pasien. Penelitian ini untuk mengetahui hubungan body image, dan sikap terhadap makanan dengan pola makan mahasiswi Politeknik Kesehatan Jurusan Gizi Banjarmasin. Jenis penelitian observasional analitik dengan rancangan cross-sectional. Penelitian dilaksanakan pada bulan April - Mei 2017 dengan sampel sebanyak 132 orang mahasiswi tingkat 1, 2 dan 3. Cara pengambilan sampel menggunakan stratified random sampling. Analisis data menggunakan uji korelasi rank Spearman dengan $\alpha=0,05$. Hasil penelitian menunjukkan sebesar 44,7 persen mahasiswi memiliki body image positif dan body image negatif sebanyak 55,3 persen mahasiswi. Sebesar 46,2 persen mahasiswi memiliki sikap terhadap makanan positif dan 53,8 persen negatif. Sebanyak 59 persen memiliki pola makan baik dan pola makan buruk 41 persen. Tidak terdapat hubungan antara body image dengan sikap terhadap makanan $(p=0,725)$, dan terdapat hubungan antara sikap terhadap makanan dengan pola makan $(p=0,016)$. Kesimpulan dari penelitian ini adalah mahasiswi Jurusan Gizi paling banyak mempunyai pola makan yang baik, sikap terhadap makanan yang negatif, dan body image yang negatif. Jurusan Gizi diharapkan dapat memberikan pengetahuan dan sosialisasi mengenai body image pada mahasiswi dengan meningkatkan asupan lauk nabati, sayur, dan buah per hari sesuai anjuran, serta menerapkan pola makan yang baik.

Kata kunci: body image, sikap terhadap makan, pola makan 


\section{PENDAHULUAN}

$\mathrm{P}$ ada tahun 2004 menurut Indonesian Societyforthe Study of Obesity (ISSO) terjadi peningkatan prevalensi overweight pada laki-laki sebesar 21,9 persen dan 49 persen mengalami obesitas sedangkan pada perempuan sebesar 19,3 persen mengalami overweight dan 38,8 persen mengalami obesitas. ${ }^{1}$ Menurut Riset Kesehatan Nasional (Riskesnas) tahun 2016 menunjukkan penduduk dewasa berusia di atas 18 tahun yang mengalami kegemukan atau obesitas sebesar 20,7 persen. Prevalensi obesitas di Kalimantan Selatan sebesar 16,5 persen. ${ }^{2}$

Salah satu kelompok usia dalam masa perkembangan adalah periode remaja dan dewasa muda. Mahasiswi dikategorikan pada tahap perkembangan yang usianya 18-25 tahun. Tahap ini dapat digolongkan pada masa remaja akhir sampai dewasa awal yang dilihat dari segi perkembangan, tugas perkembangan pada usia mahasiswi ini ialah pemantapan pendirian hidup. ${ }^{3}$

Kekhawatiran menjadi gemuk telah memaksa remaja untuk mengurangi jumlah pangan yang seharusnya disantap. ${ }^{4}$ Pada penelitian yang dilakukan di Semarang, ditemukan sebanyak 40,3 persen sampel merasa tidak puas terhadap bentuk tubuhnya dan sebagian besar subjek $(56,9 \%)$ belum menjalankan perilaku makan yang baik. ${ }^{5}$

Pembatasan dalam pola makan juga dapat dipengaruhi oleh bagaimana penilaian ataupun pandangan subyektif seseorang terhadap tubuhnya sendiri (body image). Terdapat banyak cara untuk memenuhi keinginan dalam memiliki gambaran tubuh yang ideal, salah satunya kecenderungan untuk berdiet. Diet merupakan salah satu perilaku dalam mengatur asupan makan dan pola makan seseorang. Diet dilakukan saat seseorang memiliki citra tubuh negatif cenderung merasa cemas terhadap berat badannya. ${ }^{6}$

Penelitian yang dilakukan di Semarang menyatakan sebanyak 29 remaja $(40,3 \%)$ merasa tidak puas terhadap bentuk tubuhnya dan 43 remaja $(59,7 \%)$ merasa puas terhadap bentuk tubuhnya. ${ }^{5}$ Ketidakpuasan terhadap body image rata-rata terjadi pada remaja dengan status gizi overweight dan obesitas. Terdapat pula remaja yang memiliki status gizi normal namun merasa tidak puas dengan bentuk tubuhnya. Penelitian yang dilakukan di Politeknik Kesehatan Jayapura diketahui bahwa sebagian besar responden (60,6 persen) menilai bahwa bentuk tubuhnya tidak ideal (didasarkan pada pendapat pribadi). Sebagian besar menilai bentuk tubuh mereka saat ini kurus. Penelitian ini menyatakan tubuh ideal menurut mahasiswi adalah tinggi badan sepadan dengan berat badan $(83,8 \%)$, kurus $(13,4 \%)$, overweight $(2,1 \%)$, dan obesitas $(0,7 \%)^{7}$

Pada studi pendahuluan yang dilakukan pada mahasiswi Jurusan Gizi Politeknik Kesehatan Banjarmasin, diketahui bahwa sebanyak 60,3 persen mahasiswi memiliki pola makanan yang kurang dan sisanya 39,7 persen memiliki pola makan yang baik. Pendapat body image sebanyak 27,3 persen mahasiswi merasa tidak puas dengan bentuk tubuhnya dan 72,7 persen mahasiswi merasa sudah puas dengan bentuk tubuhnya (body image positif). Mahasiswi yang merasa tidak puas dengan bentuk tubuhnya berada dalam status gizi yang baik, mereka merasa bentuk tubuh dimiliki tidak sesuai dengan yang mereka inginkan.

Peneliti tertarik mengambil subjek mahasiswi Jurusan Gizi Politeknik Kesehatan, karena mahasiswi gizi telah dibekali ilmu tentang gizi sehingga peneliti ingin mengetahui hubungan body image, sikap terhadap makanan dengan pola makan mahasiswa Jurusan Gizi Politeknik Kesehatan. Bagaimana mahasiswi menilai tubuhnya sendiri, sikapnya terhadap makanan, serta bagaimana pola makannya berdasarkan ilmu pengetahuan yang telah dimilikinya serta peneliti ingin mengetahui hubungan body images, sikap terhadap makanan, dengan pola makan mahasiswi Jurusan Gizi Politeknik Kesehatan Banjarmasin.

\section{METODE PENELITIAN}

Penelitian ini merupakan penelitian observasional analitik dan termasuk dalam lingkup gizi masyarakat. Penelitian dilakukan dengan cara pengamatan kemudian menjelaskan adanya hubungan antara variabel melalui pengujian hipotesis dengan mencari hubungan antara body image dan sikap terhadap makanan dengan pola makan mahasiswi Jurusan Gizi Politeknik Kesehatan.

Rancangan penelitian ini adalah crosssectional. Penelitian ini dilaksanakan di Jurusan 
Gizi Politeknik Kesehatan pada bulan April - Mei 2017. Populasi penelitian adalah seluruh mahasiswi Jurusan Gizi Politeknik Kesehatan tingkat 1 dan 2 Prodi D III dan D IV serta tingkat 3 Prodi D IV, dengan jumlah populasi 198 orang. Sampel untuk penelitian ini adalah mahasiswi Jurusan Gizi Politeknik Kesehatan dengan kriteria sehat jasmani dan rohani, bersedia menjadi responden, dan berada ditempat saat penelitian. Cara pengambilan sampel dengan cara stratified random sampling. Dari perhitungan sampel diperoleh 132 orang, masing-masing kelas sebanyak 27 siswa.

Jenis data yang dikumpulkan yaitu, data primer yang diperoleh secara langsung dari sampel yang meliputi: identitas responden, status gizi dengan menggunakan Indeks Massa Tubuh (IMT), body image, sikap terhadap makanan dan pola makan responden. Body Image adalah suatu penilaian mahasiswa mengenai ukuran tubuh dan penampilan fisiknya yang diperoleh dengan penjumlahan skor kemudian dirata-ratakan. Cara pengukuran body image dengan kuesioner menggunakan skala Likert dengan pernyataan positif dan negatif sehingga diperoleh body image negatif < mean skor dan body image positif $\geq$ mean skor. 8 Data sikap terhadap makanan dengan kuesioner bentuk pernyataan positif dan negatif dengan dengan pemberian skor 1,2,3 dan 4 mulai dari sangat tidak setuju, tidak setuju, setuju dan sangat setuju. Pola makan menggunakan formulir frekuensi makanan dengan pemberian skor untuk jenis, jumlah bahan makanan dan frekuensi makanan kemudian skoring dijumlahkan, kemudian dibuatkan pengkategorian menjadi pola makan baik, cukup dan kurang. ${ }^{9}$ Analisis data menggunakan uji korelasi rank Spearman dengan $\alpha=0,05$.

\section{HASIL}

\section{Karakteristik responden}

Hasil analisis berdasarkan umur responden menunjukkan bahwa usia responden terbanyak adalah dalam rentang usia 18-20 tahun sebanyak 117 orang $(88,6 \%)$ terdiri mahasiswa semester 1, 2 dan 3. Lebih dari separuh responden tinggal sendiri yaitu kost dan tinggal sendiri di rumah yaitu 95 orang $(72 \%)$ dan memiliki status gizi baik.
Hasil penelitian menunjukkan sebanyak 100 persen responden mengonsumsi jenis makanan pokok, sebanyak 1,5 persen responden tidak mengonsumsi lauk hewani, sebanyak 3,8 persen responden tidak mengonsumsi lauk nabati, 100 persen responden mengonsumsi sayuran, dan sebanyak 3 persen tidak mengonsumsi buah.

Seluruh mahasiswi mengonsumsi nasi sebagai makanan pokok utama yaitu sebanyak lebih dari satu kali sehari. Sebanyak 100 responden $(76 \%)$ mengonsumsi mi instan 4-6 kali sehari. Konsumsi makanan lain seperti roti, singkong, jagung, dan sereal rata-rata dikonsumsi 1-3 kali/minggu.

Responden rata-rata mengonsumsi lauk hewani 2-3 kali/ hari dengan jenis lauk hewani yang paling sering dikonsumsi adalah telur ayam $(87 \%)$ dan daging ayam (86\%). Lauk nabati rata-rata dikonsumsi 1 kali sehari, tahu $(84,8 \%)$ dan tempe $(90.9 \%)$ merupakan jenis lauk nabati yang paling sering dikonsumsi. Selain itu, buah rata-rata dikonsumsi 4-6 kali/hari dengan jenis buah yang paling sering dikonsumsi adalah pepaya $(61,3 \%)$, dan sayuran 1-3 kali/hari, jenis sayuran yang paling banyak dikonsumsi adalah bayam $(77,2 \%)$.

Penilaian body image responden, menunjukkan bahwa body image responden terbanyak adalah negatif sebanyak 73 orang $(55,3 \%)$. Sikap terhadap makanan pada responden menunjukkan bahwa sikap terhadap makanan responden terbanyak adalah negatif sebanyak 71 orang $(53,8 \%)$. Pola makan responden menunjukkan bahwa pola makan responden terbanyak adalah baik sebanyak 79 orang $(59 \%)$. Secara rinci dapat dilihat pada Tabel 1 berikut ini.

\section{Hubungan antara Body Image dengan Sikap terhadap Makanan}

Berdasarkan hasil analisis diketahui bahwa sebagian besar Mahasiswi Jurusan Gizi Poltekkes Banjarmasin memiliki body image negatif dengan sikap terhadap makanan yang positif yaitu 56,5 persen dan body image negatif dengan sikap terhadap makanan yang negatif adalah 54,3 persen. Tidak ada hubungan bermakna antara body image dengan sikap terhadap makanan. Hubungan body image dengan sikap terhadap makanan dapat dilihat pada Tabel 2. 
Tabel 1

Distribusi Responden Berdasarkan Body Image, Sikap terhadap Makanan dan Pola Makan

\begin{tabular}{lcc}
\hline Variabel & $\mathrm{n}=132$ & $\%$ \\
\hline Body Image & & \\
$\sim$ Positif & 61 & 46,2 \\
$\sim$ Negatif & 71 & 53,8 \\
$\begin{array}{l}\text { Sikap terhadap Makanan } \\
\sim \text { Positif }\end{array}$ & 61 & 46,2 \\
$\sim$ Negatif & 71 & 53,8 \\
Pola Makan & & \\
$\sim$ Baik & 79 & 59 \\
$\sim$ Buruk & 53 & 41 \\
\hline
\end{tabular}

Tabel 2

Hubungan Body image dengan Sikap terhadap Makanan Mahasiswi Jurusan Gizi

\begin{tabular}{|c|c|c|c|c|c|c|}
\hline \multirow{3}{*}{ Body Image } & \multicolumn{4}{|c|}{ Sikap terhadap Makanan } & \multirow{2}{*}{\multicolumn{2}{|c|}{ Jumlah }} \\
\hline & \multicolumn{2}{|c|}{ Positif } & \multicolumn{2}{|c|}{ Negatif } & & \\
\hline & $n=62$ & $\%$ & $\mathrm{n}=70$ & $\%$ & $n=132$ & $\%$ \\
\hline Positif & 27 & 43,5 & 32 & 45,7 & 59 & 100 \\
\hline Negatif & 30 & 56,5 & 43 & 54,3 & 73 & 100 \\
\hline
\end{tabular}

Tabel 3

Hubungan Sikap terhadap Makanan dengan Pola Makan Mahasiswi Jurusan Gizi

\begin{tabular}{lcccccc}
\hline \multirow{2}{*}{ Sikap terhadap Makanan } & \multicolumn{4}{c}{ Pola Makan } & \multicolumn{2}{c}{ Jumlah } \\
\cline { 2 - 6 } & \multicolumn{3}{c}{ Baik } & \multicolumn{2}{c}{ Buruk } & \\
\cline { 2 - 6 } & $\mathrm{n}=80$ & $\%$ & $\mathrm{n}=52$ & $\%$ & $\mathrm{n}=132$ & $\%$ \\
\hline Positif & 42 & 52,5 & 19 & 36,5 & 61 & 100 \\
Negatif & 38 & 47,5 & 33 & 63,5 & 71 & 100 \\
\hline \multicolumn{1}{c}{$=0,016 ; \mathrm{a}=0,05$} & & & & &
\end{tabular}

\section{Hubungan Sikap terhadap Makanan dengan Pola Makan}

Pada Tabel 3 dapat diketahui bahwa untuk responden dengan sikap terhadap makan yang positif juga memiliki pola makan yang baik $(52,5 \%)$, sedangkan responden dengan sikap negatif juga memiliki pola makan yang buruk yaitu 63,5 persen. Terdapat hubungan antara sikap terhadap makanan dengan pola makan.

\section{BAHASAN}

\section{Body Image}

Berdasarkan hasil penelitian diketahui bahwa sebagian besar responden memiliki body image negatif. Body image juga dipengaruhi oleh proses penuaan alami dan pengalaman hidup seseorang. Jika orang terluka, sakit, atau cacat, body image mereka juga akan terpengaruh. Body image negatif pada mahasiswi banyak terjadi pada mahasiswi dengan status gizi normal berdasarkan IMT $(42,4 \%)$. Hal ini disebabkan adanya pengaruh kuat dari lingkungan (media massa) dan pendidikan responden yang mengubah persepsi mahasiswi mengenai body image yang baik. ${ }^{10}$

Mereka yang mempunyai persepsi body image negatif adalah mereka dengan IMT yang berada di batas bawah IMT yaitu $18-19 \mathrm{~kg} / \mathrm{m}^{2}$, sehingga mereka menilai dirinya masih belum mempunyai proporsi tubuh yang ideal. Faktor lingkungan dan pengetahuan yang menyebabkan responden mempunyai body image negatif $(42,4 \%)$ walaupun mereka mempunyai status gizi baik, sedangkan 
responden yang mempunyai body image positif dengan status gizi normal lebih banyak yaitu 57,6 persen.

Berdasarkan tanggapan responden mengenai pernyataan yang telah disediakan di kuesioner menunjukkan bahwa body image seseorang baik yang dilihat sendiri maupun oleh orang lain, dimana penilaian orang lain ataupun persepsi lingkungan sosial mengenai body image yang ideal (trend) turut mempengaruhi penilaian body image. ${ }^{1}$

Mahasiswi yang paling banyak memiliki body image negatif yaitu tingkat III, mereka merasa masih belum mempunyai berat badan ideal, hal ini disebabkan karena mahasiswi tingkat III telah mendapatkan pengetahuan selama kuliah baik dari mata kuliah umum dan mata kuliah khusus dan berpengaruh dengan persepsinya dengan body image sebagai seorang ahli gizi. Mahasiswi yang telah mendapatkan pendidikan mengenai gizi dapat menilai tubuhnya berdasarkan ilmu pengetahuan yang telah didapatkannya sehingga mahasiswi Jurusan Gizi tingkat III lebih khawatir akan perubahan bentuk tubuhnya dan berusaha membuat dirinya sesuai dengan body image seorang ahli gizi yang dicita-citakan oleh masyarakat. Hal ini menunjukkan bahwa pengetahuan dan pendidikan gizi dapat mengubah pendapat dan tingkah laku dari mahasiswi gizi. ${ }^{1}$

\section{Sikap terhadap Makanan}

Berdasarkan hasil penelitian diketahui mahasiswi memiliki sikap terhadap makanan yang negatif. Hal tersebut disebabkan karena mahasiswi kurang menerapkan ilmu yang diberikan selama kuliah. Tingkat pendidikan sangat berpengaruh terhadap kualitas bahan makanan yang dikonsumsi. Semakin tinggi tingkat pendidikan, maka semakin positif sikap seseorang terhadap gizi makanan. ${ }^{11}$

Mahasiswi yang paling banyak memiliki sikap negatif terhadap makanan yaitu mahasiswi tingkat I $(24,4 \%)$, hal ini disebabkan karena mahasiswi tingkat I belum banyak mendapatkan pengetahuan selama kuliah dibandingkan dengan mahasiswi tingkat III baik dari mata kuliah umum dan mata kuliah khusus dan berpengaruh dengan sikapnya terhadap makanan. Hal tersebut dapat terlihat dari sebagian besar responden menyatakan sangat setuju dengan pernyataan negatif yaitu apabila berat badan yang dimiliki responden sudah normal maka responden boleh mengonsumsi energi secara berlebihan $(51,5 \%)$, dan pernyataan mengenai proses pembentukan otot, dapat dilakukan dengan mengonsumsi telur sebanyak mungkin tanpa diselingi oleh makanan lainnya $(66,7 \%)$.

Pengetahuan gizi memberikan bekal pada remaja bagaimana memilih makanan yang sehat dan mengerti bahwa makanan berhubungan erat dengan gizi dan kesehatan. Beberapa masalah gizi dan kesehatan pada saat dewasa sebenarnya bisa diperbaiki pada saat remaja melalui pemberian pengetahuan dan kesadaran tentang kebiasaan makan dan kebiasaan hidup yang sehat. ${ }^{20}$

Sikap positif seseorang terhadap makanan dan gizi yang ada, akan terbentuk jika ia mempunyai pengetahuan gizi yang cukup. Berbeda dengan orang yang kurang pengetahuan gizinya, bersikap masa bodoh dan curiga terhadap makanan tertentu yang dapat menimbulkan kekurangan gizi walaupun bahan makanan yang tersedia cukup. ${ }^{12}$

Pengetahuan gizi memberikan bekal pada remaja bagaimana memilih makanan yang sehat dan mengerti bahwa makanan berhubungan erat dengan gizi dan kesehatan. Beberapa masalah gizi dan kesehatan pada saat dewasa sebenarnya bisa diperbaiki pada saat remaja melalui pemberian pengetahuan dan kesadaran tentang kebiasaan makan dan kebiasaan hidup yang sehat. Salah satu penyebab timbulnya masalah gizi dan perubahan kebiasaan makan pada mahasiswi adalah kesadarannya terhadap gizi dan makanan yang rendah. Mahasiswi yang memiliki kesadaran gizi yang baik akan lebih mampu memilih makanan sesuai dengan kebutuhannya. ${ }^{12}$

\section{Pola Makan}

Berdasarkan penelitian pola makan mahasiswi berada pada pola makan yang baik.Selanjutnya, diketahui bahwa sebanyak 18,1 persen responden tidak menerapkan pola makan yang dianjurkan yaitu makan tiga kali sehari dengan tiga kali makan utama dan dua kali selingan. Kehidupan mahasiswi menyebabkan terjadi perubahan pola makan. ${ }^{8}$ Mereka terdiri dari mahasiswa tingkat 3 juga, walaupun dalam keilmuannya sudah mengetahui penerapan pola makan yang baik. 
Makanan pokok selain nasi yang sering dikonsumsi responden adalah mi instan. Pada mahasiswi, mie instan masih menjadi salah satu jenis makanan yang dipertimbangkan untuk memenuhi rasa lapar selain itu, kecenderungan mengonsumsi $\mathrm{mi}$ instan oleh responden sebagai sumber energi dalam melakukan kegiatan atau aktivitas sehari-hari.

Berdasarkan jumlah yang dikonsumsi oleh responden untuk jenis lauk nabati, buah, dan sayur tidak sesuai dengan jumlah konsumsi bahan makanan menurut pedoman umum gizi seimbang. Jumlah konsumsi lauk nabati masih belum mencapai standar menurut Pedoman Umum Gizi Seimbang (PUGS) yaitu lebih dari 100 gram/hari. ${ }^{9}$

Hal ini disebabkan karena responden tidak memperhatikan jumlah lauk nabati yang dikonsumsinya. Perubahan kehidupan sosial dan kesibukan sebagai mahasiswi mempengaruhi pola makan mereka terutama perubahan selera yang akan jauh dari konsep seimbang yang berdampak pada kesehatan. ${ }^{8}$ Selain itu, kurangnya jumlah lauk nabati yang dikonsumsi dikarenakan sebagian besar responden tinggal sendiri (kos), sehingga cenderung memilih membeli makanan daripada membuat makanan sendiri.

Rata-rata konsumsi sayur dan buah mahasiswi masih di bawah anjuran Pedoman Gizi Seimbang yaitu > $200-300$ gram/hari. Hal ini dapat diketahui bahwa pola makan orang dewasa saat ini cenderung kurang mengonsumsi buah dan sayur. ${ }^{8}$ Rata-rata penduduk di Provinsi Kalimantan Selatan untuk kelompok umur remaja dan dewasa (13-18 tahun dan 19-55 tahun) mengonsumsi sayur dan buah beserta olahannya hanya mencapai 31,4 gram per orang per hari yang merupakan jumlah yang sangat kecil. Faktor yang menyebabkan tidak terpenuhnya pola makan berdasarkan PUGS kemungkinan besar akibat budaya dan sosial dari masyarakat Indonesia. Kurangnya porsi makanan yang seharusnya dipenuhi akan menyebabkan ketidakseimbangannya asupan zat gizi yang dibutuhkan oleh tubuh. ${ }^{10}$

\section{Hubungan Body Image dengan Sikap terhadap Makanan}

Berdasarkan hasil penelitian diketahui bahwa tidak ada hubungan bermakna antara body image dengan sikap terhadap makanan
Mahasiswi Jurusan Gizi Poltekkes Banjarmasin. Hasil penelitian menunjukkan sebanyak 56 responden (42,4 persen) dengan status gizi normal merasa tidak puas dengan bentuk tubuhnya. Hasil tersebut sejalan dengan penelitian yang menyatakan bahwa terdapat 12,5persen remaja merasa gemuk namun memiliki status gizi yang normal. ${ }^{5} \mathrm{Hal}$ ini memperlihatkan bahwa meskipun subjek telah mempunyai tubuh ideal namun mereka cenderung menilai ukuran tubuhnya lebih besar atau kecil dari ukuran sebenarnya.

Sebagian besar mahasiswi lebih memperhatikan berat badan dan bentuk tubuhnya dibandingkan dengan makanan. Hal ini berakibat pada pembatasan asupan makanan yang keliru. Pembatasan konsumsi makanan yang tidak memperhatikan kaidah gizi dan kesehatan untuk mendapatkan tubuh yang ideal (langsing), justru akan berdampak negatif pada status gizi remaja terlebih kepada mahasiswi. $^{5}$

Hasil penelitian ini sependapat dengan penelitian yang menyatakan tidak ada hubungan antara body image dengan sikap terhadap makanan. ${ }^{13}$ Subjek penelitian yang memiliki body image yang tinggi, maka kecenderungan pengambilan sikapnya terhadap makanan yang dilakukan akan semakin rendah. Hal tersebut terlihat dari responden yang sudah memiliki status gizi normal masih menginginkan penurunan berat badan, dengan alasan merasa tidak puas dengan bentuk tubuhnya. ${ }^{13} \mathrm{Hal}$ ini, menimbulkan persepsi yang salah mengenai sikapnya dalam memilih makanan yang akan dikonsumsi. Ketidakpuasan terhadap bentuk tubuh pada remaja dengan menganggap tubuhnya terlalu gemuk membuat remaja melakukan upaya penurunan berat badan dengan cara yang salah. Hal ini mengakibatkan banyak remaja yang mengontrol berat badan dengan melakukan diet dan berolahraga secara berlebihan untuk membentuk tubuh yang ideal. ${ }^{14}$

Variabel body image tidak sepenuhnya mempengaruhi sikap terhadap makanan. Faktor-faktor lain yang dapat berdampak terhadap sikap terhadap makanan, diantaranya adalah jenis kelamin dan pendapatan. Jenis kelamin menentukan besar kecilnya kebutuhan gizi bagi seseorang. Ketidakpuasan terhadap tubuh lebih banyak terjadi pada remaja perempuan dari pada remaja laki-laki. Laki-laki 
lebih banyak membutuhkan zat tenaga dan protein daripada perempuan, karena laki-laki memang diciptakan untuk tampil lebih aktif dan lebih kuat dari pada perempuan. ${ }^{8}, 15 \mathrm{Hal}$ ini dapat dilihat dari jenis pekerjaan yang dilakukan oleh laki-laki dan perempuan. Laki-laki lebih sanggup menyelesaikan pekerjaan berat yang biasanya tidak bisa dilakukan perempuan. Kegiatan perempuan pada umumnya lebih banyak membutuhkan keterampilan tangan dan kurang memerlukan tenaga. ${ }^{15,16,17}$ Perempuan lebih banyak mempunyai pengetahuan tentang makanan dan gizi serta menunjukkan perhatian yang lebih besar terhadap keamanan makanan, kesehatan, dan penurunan berat badan.

Pendapatan merupakan salah satu faktor yang ditengarai dapat mempengaruhi sikap seseorang terhadap makanan biasanya seseorang akan memilih makanan yang sesuai dengan uang saku mereka, dengan uang saku yang cukup besar biasanya seseorang akan sering memilih makanan-makanan yang modern dengan pertimbangan prestice dan harapan akan diterima kalangannya. ${ }^{18,19,20}$

\section{Hubungan Sikap terhadap Makanan dengan Pola Makan}

Berdasarkan hasil penelitian diketahui terdapat hubungan bermakna antara sikap terhadap makanan dengan pola makan. Penelitian ini sependapat dengan penelitian yang dilakukan di Jakarta yang menyatakan bahwa adanya hubungan yang bermakna antara sikap pemenuhan gizi dengan pola makan pada mahasiswi dan kurangnya pengetahuan akan menyebabkan sikap yang salah atau negatif dalam memenuhi kebutuhan pangan. $8,18,19$

Pada penelitian ini dapat disimpulkan mahasiswi memiliki sikap terhadap makanan yang negatif namun memiliki pola makan yang baik. Hal tersebut dikarenakan sikap terhadap makanan atau gizi merupakan kecenderungan seseorang untuk menyetujui atau tidak menyetujui terhadap suatu pernyataan yang diajukan. Sikap belum merupakan tindakan atau aktivitas, akan tetapi merupakan tindakan atau predisposisi tindakan suatu perilaku. Sikap itu merupakan suatu kesiapan untuk bereaksi terhadap objek di lingkungan tertentu sebagai suatu penghayatan terhadap objek. ${ }^{15}$

Pola makan merupakan perilaku manusia dalam memenuhi kebutuhan akan makanan yang meliputi jenis makanan, frekuensi, cara pengolahan, dan pemilihan makanan. 16,20, 21, 22,23 Hal ini, dapat disimpulkan bahwa sikap terhadap makanan merupakan suatu ketersediaan untuk bertindak sedangkan pola makan merupakan tindakan tersebut. Rendahnya sikap terhadap makanan pada mahasiswi jurusan gizi dikarenakan kehidupan responden sebagai mahasiswi yang menyebabkan responden lebih memilih makanan praktis yang membuat kenyang lebih cepat contohnya seperti fast food atau mi instan serta kurangnya kesadaran untuk memilih makanan yang baik berdasarkan kandungan gizi dari makanan tersebut. 22,23,24,25,

Sikap dalam memilih makanan selain terbentuk dari kesadaran individu dalam menentukan makanan yang akan dikonsumsi. Selain itu sikap juga dipengaruhi oleh kebudayaan dan lembaga pendidikan tempat seseorang itu bersekolah. ${ }^{17}$ Lembaga pendidikan sebagai suatu sistem pembentukan sikap karena meletakkan dasar pengertian dan konsep kepada orang yang dididik terlebih kepada mahasiswi gizi dengan pendidikan yang lebih fokus pada gizi sehingga dapat menerapkan pengetahuannya dalam

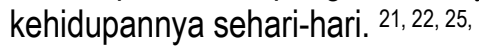

\section{SIMPULAN DAN SARAN}

\section{Simpulan}

Kesimpulan dalam penelitian ini adalah tidak ada hubungan body image dengan sikap terhadap makanan pada mahasiswa Jurusan Gizi Politeknik Kesehatan. Ada hubungan sikap terhadap makanan dengan pola makan pada mahasiswi Jurusan Gizi Politeknik Kesehatan.

\section{Saran}

Kerja sama antara pihak akademik dengan organisasi profesi (PERSAGI) untuk memberikan edukasi dalam bentuk seminar dan kuliah tamu bagi mahasiswi tentang body image terhadap berat badan yang ideal bagi ahli gizi. Bagi Responden agar dapat memilih makanan dan minuman sehat untuk dikonsumsi seharihari serta meningkatkan asupan lauk nabati, sayur dan buah per hari sesuai anjuran, menerapkan pola makan yang baik berupa tiga kali makan utama dengan satu selingan sesuai dengan anjuran pedoman gizi seimbang. 


\section{UCAPAN TERIMA KASIH}

Terima kasih disampaikan kepada Ketua Jurusan Gizi Politeknik Kesehatan yang telah memberikan kesempatan dan fasilitas dalam kegiatan penelitian ini.

\section{RUJUKAN}

1. Padmawati. Persepsi Mahasiswi Program Studi Gizi Kesehatan Terhadap Citra Tubuh Ahli Gizi. Jurnal Gizi Klinik Indonesia. 2011; 8((1): 42-49.

2. Mahdiah, Hadi $\mathrm{H}$, Susetyowati. Prevalensi obesitas dan hubungan konsumsi fastfood dengan kejadian obesitas pada remaja SLTP kota dan desa di Daerah Istimewa Yogyakarta. Jurnal Gizi Klinik Indonesia 2004; 1(2): 77-85.

3. Yusuf, Syamsu. Psikologi Perkembangan Anak dan Remaja. Bandung: Remaja Rosdakarya. 2012.

4. Abdurrahman Fadlullah. Faktor Pendorong Perilaku Diet Tidak Sehat pada perempuan Usia Dewasa Awal . studi Kasus pda Mahasiswa univeritas Mulawarman. E Journal Psikologi. 2014:2(2): 153-170.

5. Widianti, Nur. Hubungan Antara Body image dan Perilaku Makan dengan Status Gizi Remaja Putri di SMA Theresiana Semarang. Journal of Nutrition College. 2012;1(1):400-421.

6. Rahmawati D A. Hubungan Antara Citra Tubuh dan Kontrol Diri pada Pola Makan Remaja Putri di SMK Negeri 2 Godean. Skripsi. Yogyakarta: Universitas Islam Negeri Yogyakarta, 2013.

7. Sada, Merinta. Hubungan Body image, Pengetahuan Gizi Seimbang, Dan Aktivitas Fisik terhadap Status Gizi Mahasiswi Politeknik Kesehatan Jayapura. Jurnal Media Gizi Masyarakat Indonesia. 2012;2(1): 44-46.

8. Kemenkes RI. Pedoman Umum Gizi Seimbang. Jakarta. 2014.

9. Farida, Ida. Faktor-Faktor yang Berhubungan Dengan Perilaku Konsumsi Buah dan Sayur Pada Remaja di Indonesia Tahun 2007. Skripsi. Jakarta: Universitas Islam Negeri Syarif Hidayatullah, 2007.

10. PlannedParenthoodFederation of America Inc. 2017. Body image. Artikel. https://www.plannedparenthood.org/learn/bodyimage.

11. Ramadhani Stevea Tafdial, Badraningrum. Hubungan Perilaku Konsumsi makan Senat dengan Status Gizi Mahasiswa Pondok Pesantren Wahid Hasyim Yogyakarta. E Journal Student Pendidikan Teknik Boga. 2016;5(4): 80-84.

12. Rhida Muhamad. Hubungan Antara Body Image dengan Penerimaan Diri pada Mahasiswa Aceh. Emphaty Jurnal Fakultas Psikolog Yogyakarta. 2012;1(2): 65-68.
13. Chairiah, Putri. 2012. Hubungan Gambaran Body image dan Pola Makan Remaja Putri di SMAN 38 Jakarta. Skripsi. Fakultas IImu Keperawatan. Universitas Indonesia, 2012.

14. Notoatmojo, S. Pendidikan dan Perilaku Kesehatan. Jakarta: PT Rineka Cipta. 2003.

15. Susanti, Erma. Hubungan Aktivitas Fisik dan Sikap Terhadap Makanan dengan Status Gizi Mahasiswi Jurusan Gizi. Karya Tulis IImiah. Banjarbaru: Politeknik Kesehatan Banjarmasin, 2014.

16. Soehardjo. Sosio Budaya Gizi. Bogor (ID): Departemen Pendidikan dan Kebudayaan, Direktorat Jenderal Pendidikan Tinggi, PAU Pangan dan Gizi, IPB. 1989.

17. Irawati Septian Dini, Safitri. Hubungan antara Body image dan perilaku Diet Mahasiswai Universitas Esa Unggul. Jurnal Psikologi. 2014;12(1): 20-24.

18. Anggraenio, Sebtina Desty. Hubungan Antara Body Image dengan Frekuensi Makan, Jenis makanan dan Status Gizi Remaja Putri di SMA 7 Surakarta. Tesis. Universitas Muhamadyah Surakarta, 2015

19. Fauziah Trieyani Ekksa. Hubungan Pola Konsumsi Pangan Sumber lemak dan Kebiasaan Olahraga dengan Komposisi Lemak Tubuh dan Kebugaran pada Mahasiswa IPB. Skripsi. IPB, 2014.

20. Emilia Esi. Pengetahuan, Sikap dan Praktek Gizi pada Remaja dan Implikasinya pada Sosialisasi Perilaku Hidup Sehat. Media Pendidikan Gizi dan Kuliner. 2009;1(1).

21. Kusumajaya NAA, NK Wardabu. Persepsi Terhadap Body Image kaitannya dengan Pola Konsumsi makanan dan Status Gizi. Jurnal Skala Husada. 2012;5( 2):124-125.

22. Fernanda Laus Maria, Michele Ghidini Souza. Body Image Dissatisfaction, Nutritional Status and Eating Attitudes in Adolecents. Health Sciences. 2013;35(2):25-28.

23. Kurniawan Mohamad Yulianto, Dodik Briawan. Persepsi Tubuh dan ganggyan makan pada remaja perempuan. JGP. 2014; 9(2):103-108.

24. Janastin Hastuti. Anthropometryand Body Composition of Indonesia Adults: an Evaluation of Body Image, eating Behaviour and Physical Activity, 2013. Thesis. Queensland University of Technologi. 2013.

25. Rahayu Santi Dwi, Fillah Fithra Dieny. Citra Tubuh, Pendidikan lbu, Pendapat Keluarga, Pengetahuan Gizi, Perilaku Makan dan Asupan zat Gizi pada Siswa SMA. Media Medika Indonesia. 2012;46(3):120-124. 